ice during flights in recent years, that the land-ice round this coast is heavily crevassed and would make travelling difficult. On the other hand, he thinks that the sea-ice will give a suitable surface and that lines of stranded bergs prevent it breaking up near the coast. The experience of others in the Weddell Sea suggests that these are optimistic views, but Capt. Riiser-Larsen admits that if the route proves impracticable, journeys will be made in an easterly direction from Enderby Land, where there is much work to be done. The use of a sea-ice route will certainly allow plenty of seal-meat to be got for men and dogs, and so obviate the necessity of carrying full rations.

\section{Institution of Mechanical Engineers}

AT the annual general meeting of the Institution of Mechanical Engineers on February 17, Mr. A. E. L. Chorlton, M.P., was inducted as president and the annual report for 1932 was adopted. The total membership of the Institution is now 11,295, a net increase for the year of 134. While the numbers of associate members and graduates show considerable increases, there has been a decrease in the numbers of members and of students. During the year Sir Alfred Ewing, Sir Henry Fowler, Sir Vincent Raven, Sir J. J. Thomson and the late Mr. W. H. Patchell were elected honorary life members. The total revenue for the year was $£ 34,052$. The report refers to the work of the various research committees and also to the educational work done. Examinations for National Certificates and Diplomas in Mechanical Engineering were held in conjunction with the education departments in England, Scotland and Northern Ireland at which 2,829 candidates sat. Twenty National Diplomas (Air) in Mechanical Engineering were awarded jointly with the Board of Education and the Air Ministry to officers of the Royal Air Force on completion of the engineering course at Henlow. In addition to the meetings held at the headquarters of the Institution, full programmes were carried out by the nine provincial branches, the average attendance of members and visitors at each meeting being more than a hundred. The gifts to the Institution include a plaque modelled by F. J. Halnon and cast in steel, showing Faraday in his laboratory, the donor being Sir Robert Hadfield.

\section{Illuminated Fountains}

RECENT installations of illuminated fountains in Paris and Stockholm prove that magnificent effects can be produced in this way which fit in well with festive occasions. In the Escher-Wyss News for October an interesting technical description is given of an illuminated fountain which was constructed in the lake of Zurich for a 'lighting week'. A pontoon was moored 85 metres distant from the shore and away from the route of the steamer's. The caisson is circular in shape, its weight is 12 tons and the upper platform is ten metres in diameter. Five pump sets are arranged in the bottom of the caisson each capable of delivering $220 \mathrm{lb}$. of water per second when the motors rotate at 1,450 r.p.m., producing a total pressure head of 20 metres. They can be connected in series or parallel. The play of the water is arranged in eight different ways producing the appearance of circles, tulips, baskets, etc. With one arrangement the main water jet rises to a height of 45 metres, the whole fountain being apparently enveloped in foam. The whole of the playing waters are illuminated by thirty-two search-lights, each taking between 1,000 and 1,500 watts. The lamps are hermetically sealed in concrete casings. The entire pontoon is painted in a neutral colour so as not to form a contrast and interfere with the picture presented by the lake. The general effect of this fountain fits in very well with the shore illuminations. The work was completed in a few weeks and the fountain was set in operation on October 1, 1932.

\section{Steam, Electric and Diesel-Electric Traction}

IN a paper read before the Institution of Civil Engineers on February 21, H. W. H. Richards, electrical engineer to the London and North Eastern Railway, makes a definite comparison, both technical and financial, between steam, electric and Dieselelectric traction. The comparison is based on the existing traffic conditions of load and speed, so that it is on exactly the same basis in each case. It can be shown that the most satisfactory unit to adopt is the trailing ton-mile per annum per single track. The average traffic density for steam trains is about three million ton-miles and for electric trains which are practically confined to suburban service it is about 4.5 million ton-miles. It appears that on an average load of about fifty per cent for the complete electrification of the main lines in Great Britain, the total power of the steam turbines required for the electric service would be $\mathbf{3 \cdot 5}$ million brake horse power. If Diesel-electric service were adopted throughout, the total Diesel engine power required would be 15 million brake horse power. On the same basis, the total weight of electric tractors would amount to 850 thousand tons as compared with 1,300 thousand tons for Diesel-electric tractors. The capital costs for traffic densities ranging from 2 million to 10 million ton-miles are in all cases cheapest for steam and the costs of electric and Diesel-electric services are much the same at a traffic density of 4 million, after which electric traction becomes progressively cheaper. As regards operating costs, for main line services, including interest on capital, the cost of electric traction is lower than that of steam or Diesel-electric traction at traffic densities greater than $2 \cdot 5$ million ton-miles.

\section{Reading under Vibratory Conditions}

IN the paper on recent developments on electric lighting read by Mr. W. J. Jones to the Royal Society of Arts on November 30 and published in the Society's journal (J. Roy. Soc. Arts, vol. 81, p. 132) some novel experiments and phenomena were described in connexion with illumination. He showed a swinging pendulum with the letter $E$ printed at various points down its shaft. The speed of translation of any particular $E$ is directly proportional to its 